\title{
Hijab Fashion Consciousness and Consumption Among Generations X and $Y$
}

\author{
Farida Hasna ${ }^{a}$ and Sri Rahayu Hijrah Hati, ,b, \\ ${ }^{1}$ Management Department Faculty of Economics and Business Universitas Indonesia-Depok, \\ Indonesia \\ ${ }^{2}$ Management Department Faculty of Economics and Business Universitas Indonesia-Depok, \\ Indonesia \\ afarida.hasna@ui.ac.id, bsri.rahayu72@ui.ac.id \\ ${ }^{*}$ Corresponding author
}

\begin{abstract}
Keywords: Hijab, fashion consciousness, consumption, generation $X$, generation $Y$
Abstract. Marketers believe that they should treat generations $\mathrm{X}$ and $\mathrm{Y}$ as two different market segments, including when they offer a fashion product. Islam has strict laws regarding women's fashion: All women should cover their head and body using a veil or hijab regardless of their cohort or age. This study aims to examine the influence of cohort on hijab fashion-related attitude and consumption behaviour. The study finds no significant differences between generations $\mathrm{X}$ and $\mathrm{Y}$ in terms of dressing style, source of fashion knowledge, fashion motivation, fashion uniqueness, hijab fashion consciousness or social network site-related behaviour. The study also finds that the significant differences between generations $\mathrm{X}$ and $\mathrm{Y}$ in terms of hijab fashion consciousness are influenced by level of income and level of fashion expenditure.
\end{abstract}

\section{Introduction}

Currently, research reports mixed results regarding the impact of cohort on consumer behaviour. Some scholars have found that, to some extent, only very slight or no significant differences exist between generation $\mathrm{X}$ and generation $\mathrm{Y}$ consumer behaviour [1]. Some variables, such as marketrelated situations and level of economic development, moderate the relationship between cohort and consumer behaviour [1]. One study on Taiwan's generations $\mathrm{X}$ and $\mathrm{Y}$ found that despite the significant difference in compulsive buying tendency, no significant difference exists in terms of most money-related attitudes between those cohorts [2].

However, most marketers who target generation $\mathrm{Y}$ highly trust that the $\mathrm{Y}$ generation is dissimilar in many ways (e.g., attitude towards advertising, purchasing behaviour, and shopping involvement) from generation X or the baby boomers [3]-[5]. Previous studies show that generation $Y$ tends to be less brand loyal, less risk averse, more hedonist, more connected to the internet, with a more extravagant lifestyle and different media preferences than generation X [3], [6], [7]. In the context of fashion products, generation $Y$ tends to have higher frequency of purchase, fashion fanship, attitude and impulse buying than other cohorts [8].

Related to the fashion issue, Islam has its own special rules on what kind of fashion Muslim women should wear, regardless of their age or cohort. Under Islamic law, all Islamic women should wear a veil or hijab [9]. To date, almost no studies have examined the influence of age or cohort on fashion product-related consumption. The current study aims to examine the impact of cohort, especially between generation $\mathrm{X}$ and generation $\mathrm{Y}$ fashion-related attitude and behaviour.

\section{Literature Review}

\subsection{Generational Cohort Theory}

According to generational cohort theory, significant historical events and societal changes influence individuals' values, attitudes, beliefs and disposition [10]. Currently, mixed results have been reported regarding the impact of cohort on consumer values, attitudes, beliefs and behaviour. Some 
scholars have found no significant influence on attitude and behaviour in different cohorts [2], while others have found that cohort plays significant role in consumer attitude and behaviour [3], [6], [7].

\subsection{Hijab Consumption}

One current study in the context of hijab consumption found that dressing style, source of fashion knowledge, fashion motivation, fashion uniqueness and fashion consciousness play significant roles in Muslim women's hijab consumption [11].

From the Islamic perspective, the dress code for Muslim women is part of Islamic teaching regardless of the cohort or age.

"O Prophet! Tell your wives and your daughters and the women of the believers to draw their cloaks (veils) all over their bodies (i.e. screen themselves completely except the eyes or one eye to see the way). That will be better, that they should be known (as free respectable women) so as not to be annoyed. And Allah is Ever Oft-Forgiving, Most Merciful” [al-Ahzaab 33:59]

Another Hadeeth narrated by al-Bukhaari, 4481 and Abu Dawood (4102) also emphasises the importance of the veil or hijab:

May Allah have mercy on the Muhaajir women. When Allaah revealed the words "and to draw their veils all over Juyoobihinna (i.e. their bodies, faces, necks and bosoms)", they tore the thickest of their aprons (a kind of garment) and covered their faces with them.

\section{Method}

Data are collected via an online survey of 392 Muslim women who wear hijab. The questionnaire addresses dressing style, source of fashion knowledge, fashion motivation and fashion uniqueness [11]. All the variables are measured using a 5-point Likert scale with statements anchored by "strongly disagree" (1) and "strongly agree" (5).

\subsection{Descriptive analysis}

Based on the online survey (see Table 1), most of the respondents were generation $\mathrm{Y}(88.8 .67 \%)$, working as a student (76.7\%), with an income of IDR 600.000-1.000.000 (93\%) and fashion expenditure less than IDR $500.000(75 \%)$.

Table 1. Descriptive Statistics

\begin{tabular}{|c|c|c|c|}
\hline Variable & Description & Number & Percentage \\
\hline \multirow[t]{3}{*}{ Generation } & $\mathrm{X}(38-57$ years old $)$ & 44 & 11.2 \\
\hline & Y (17-37 years old) & 348 & 88.8 \\
\hline & Total & 392 & 100.0 \\
\hline \multirow[t]{6}{*}{ Occupation } & Student & 301 & 76.7 \\
\hline & Entrepreneur & 12 & 3.1 \\
\hline & Government employee & 18 & 4.6 \\
\hline & Private employee & 30 & 7.7 \\
\hline & Homemaker & 31 & 7.9 \\
\hline & Total & 392 & 100.0 \\
\hline \multirow[t]{5}{*}{ Income } & $<600.0000$ & 53 & 13.5 \\
\hline & IDR 600.000 - IDR 1.000 .000 & 129 & 32.9 \\
\hline & IDR 1.000 .000 - IDR 1.800 .000 & 94 & 24.0 \\
\hline & IDR 1.800 .000 - IDR 3.000 .000 & 52 & 13.3 \\
\hline & > IDR 3.000 .000 & 64 & 16.3 \\
\hline
\end{tabular}


Table 1, cont.

\begin{tabular}{llcc}
\hline & Total & 392 & 100.0 \\
\hline Expenditure & $<500.0000$ & 294 & 75.0 \\
\cline { 2 - 4 } & IDR 500.000 - IDR 1.000.000 & 69 & 17.6 \\
\cline { 2 - 4 } & IDR 1.000.000 - IDR 1.500.000 & 22 & 5.6 \\
\cline { 2 - 4 } & IDR 1.500.000 - IDR 2.000.000 & 5 & 1.3 \\
\cline { 2 - 4 } & IDR 2.000.000 -IDR 2.500.000 & 1 & .3 \\
\cline { 2 - 4 } & $>$ IDR 2.500.000 & 1 & 74.5 \\
\cline { 2 - 4 } & Total & 292 & \\
\hline
\end{tabular}

\subsection{Comparison of mean across generations and demographic variables}

Independent t-tests were utilised to test for any significant difference between generation $\mathrm{X}$ and generation $\mathrm{Y}$ in terms of dressing style, source of fashion knowledge, fashion motivation, fashion uniqueness, hijab fashion consciousness and social network site-related behaviour. The results show no significant differences between generations $\mathrm{X}$ and $\mathrm{Y}$ (Table 2) in all fashion-related attitudes and behaviour ( $\mathrm{Sig}>0.05)$ except for social network site-related behaviour $(\mathrm{Sig}=0.00)$.

Table 2. Independent Sample T-Test of Generation X and Generation Y.

\begin{tabular}{lccc}
\hline Variable & Mean Generation & Mean Generation & Sig \\
& $\mathrm{X}$ & $\mathrm{Y}$ & \\
\hline Dressing style & 3.65 & 3.66 & 0.81 \\
\hline Source of fashion knowledge & 3.27 & 3.33 & 0.49 \\
\hline Fashion motivation & 3.27 & 3.25 & 0.88 \\
\hline Fashion uniqueness & 3.02 & 3.10 & 0.52 \\
\hline Fashion consciousness & 2.98 & 3.05 & 0.64 \\
\hline Hijab fashion consumption & 2.68 & 2.89 & 0.12 \\
\hline Social network sites & 3.19 & 3.68 & 0.00 \\
\hline
\end{tabular}

To check whether the demographic variables income and expenditure influence customer attitude and consumption in the fashion context, the researchers conducted one-way analysis of variance (ANOVA). The results show that income influences hijab fashion consumption $(\mathrm{F}=3.30$; $\mathrm{Sig}=0.01)$. The results also show that expenditure significantly influences customer fashion uniqueness $(\mathrm{F}=2.74$; Sig=0.01), fashion consciousness $(\mathrm{F}=3.51 ; \mathrm{Sig}=0.00)$ and hijab fashion consumption $(\mathrm{F}=3.51$; Sig=0.01).

Table 3. One-Way ANOVA based on Income and Expenditure

\begin{tabular}{lcccc}
\hline & \multicolumn{2}{c}{ Income } & \multicolumn{2}{c}{ Expenditure } \\
\hline Variable & F & Sig & F & Sig \\
\hline Dressing style & 2.13 & 0.07 & 1.83 & 0.09 \\
\hline Source of fashion knowledge & 0.82 & 0.51 & 1.77 & 0.10 \\
\hline Fashion motivation & 0.98 & 0.41 & 1.42 & 0.20 \\
\hline Fashion uniqueness & 0.82 & 0.51 & 2.74 & $0.01^{*}$ \\
\hline Fashion consciousness & 2.09 & 0.08 & 3.51 & $0.00^{*}$ \\
\hline Hijab fashion consumption & 3.30 & $0.01^{*}$ & 2.72 & $0.01^{*}$ \\
\hline Social network sites & 1.10 & 0.35 & 1.43 & 0.19 \\
\hline
\end{tabular}

\section{Summary}

The study shows that in the context of hijab consumption by Muslim women, the cohort does not play a significant role. However, the study also shows the probability that several other variables, such as 
religiosity, might play a role in the relationship regardless of the cohort. In addition, the study reveals that income and expenditure significantly influence hijab fashion consumption.

\section{Acknowledgement}

This research was supported financially by a PITTA Grant to DRPM Universitas Indonesia.

\section{References}

[1] C. Gurdu, "A life-stage analysis of consumer loyalty profile: comparing Generation X and Millennial consumers," J. Consum. Mark., vol. 29, no. 2, pp. 103-113, 2013.

[2] C. Hsiao and W. Chang, "The Relationship Between Money Attitude and Compulsive Buying Among Taiwan's Generation X and Y," J. Accounting, Financ. Manag. Strateg., vol. 3, no. 2, p. 95, 2007.

[3] B. Jorgensen, "Baby Boomers, Generation X and Generation Y?: Policy implications for defence forces in the modern era," Foresight, vol. 5, no. 4, pp. 41-49, 2003.

[4] A. Parment, "Generation Y vs. Baby Boomers: Shopping behavior, buyer involvement and implications for retailing," J. Retail. Consum. Serv., vol. 20, no. 2, pp. 189-199, 2013.

[5] H. Ting and E. C. de Rum, "Generations X and Y Attitude towards Controversial Advertising," Asian J. Bus. Res., vol. 2, no. 2, pp. 24-37, 2012.

[6] S. Lissitsa and O. Kol, "Generation X vs. Generation Y - A decade of online shopping," J. Retail. Consum. Serv., vol. 31, pp. 304-312, 2016.

[7] G. Bennett, M. Sagas, and W. Dees, "Media Preferences of Action Sports Consumers: Differences Between Generation X and Y," Sport Mark. Q., vol. 15, no. 1, pp. 40-49, 2006.

[8] R. Pentecost and L. Andrews, "Fashion retailing and the bottom line: The effects of generational cohorts, gender, fashion fanship, attitudes and impulse buying on fashion expenditure," J. Retail. Consum. Serv., vol. 17, no. 1, pp. 43-52, 2010.

[9] D. Zwick and C. Chelariu, "Mobilizing the Hijab: Islamic identity negotiation in the context of a matchmaking website," J. Consum. Behav., vol. 5, pp. 380-395, 2006.

[10] S. Moss, "Generational cohort theory," 2016. [Online]. Available: http://www.sicotests.com/psyarticle.asp?id=374. [Accessed: 08-Apr-2017].

[11] S. H. H. H. Harun, "Factors influencing fashion consciousness in hijab fashion consumption among hijabistas," J. Islam. Mark., vol. 7, no. 4, pp. 476-494, 2016. 